\title{
Dinuclear Zinc (II) Complexes of Macrocyclic Polyamine Ligands Containing an Imidazolium Bridge: Synthesis, Characterization, and Their Interaction with Plasmid DNA
}

Jun Huang ${ }^{1}$, Qing-Dong Huang ${ }^{1}$, Ji Zhang ${ }^{1}$, Li-Hong Zhou ${ }^{1}$, Qiang-Lin ${ }^{2 i}{ }^{1}$, Kun Li ${ }^{1}$, Ning Jiang ${ }^{2}$, Hong-Hui Lin ${ }^{2, *}$, Jiang $\mathrm{Wu}^{1 \text {,* }}$ and Xiao-Qi Yu ${ }^{1,3, *}$

1 Department of Chemistry, Key Laboratory of Green Chemistry and Technology (Ministry of Education), Sichuan University, Chengdu, 610064, P. R. China

2 Key Laboratory of Bio-resources and Eco-environment (Ministry of Education), College of Life Sciences, Sichuan University, Chengdu, Sichuan, 610064, P. R. China

3 State Key Laboratory of Biotherapy, West China Hospital, West China Medical School, Sichuan University, Chengdu, Sichuan 610041, P. R .China

* Author to whom correspondence should be addressed. Fax: +86 28 85415886;

E-mail: xqyu@tfol.com

Received: 6 March 2007; in Revised Form: 6 June 2007 / Accepted: 14 June 2007 /

Published: 4 July 2007

\begin{abstract}
Two novel macrocyclic polyamine ligands and their dinuclear zinc (II) complexes were synthesized and characterized. Their interaction with plasmid DNA was studied by gel electrophoresis and fluorescence quenching experiment. The result showed that these complexes could bind DNA efficiently under physiological conditions.
\end{abstract}

Keywords: 1, 4, 7, 10-tetraazacyclododecane (cyclen); zinc (II) complexes; imidazolium; synthesis; DNA protection.

\section{Introduction}

Genetic engineering has brought new challenges and opportunities for medicine and biomedical research, whereas DNA strands would be damaged in cellular environment [1-3]. The damage of DNA would cause mutations and genomic instabilities that may contribute to a variety of human genetic diseases. Thus DNA protection may play a significant role in bioanalysis and delivery. Though a few 
methods have been taken to protect DNA [4-8], there were very few reports on small molecules that could protect DNA. He et al. found out that protonation of the amino-modified silica nanoparticles could protect DNA due to the ability to enrich the negatively charged DNA strands by the positive charges on these materials [4]. Imidazolium ionic liquids with cations were thus expected to bind DNA sequences. Additionally, ionic liquids applied in biological chemistry were studied recently [9, 10]. Ohno and colleagues prepared ionic liquid-robed DNAs by using the cations from imidazole ring to fix the phosphate group of DNA $[11,12]$.

1,4,7,10-tetrazacyclododecane (cyclen) is a representative macrocyclic polyamines compound and shows high binding affinity with transition metal ions, such as $\mathrm{Zn}$ (II), $\mathrm{Cu}$ (II) and $\mathrm{Co}$ (II) [13-16]. A number of research groups have reported macrocyclic polyamines metal complexes especially multinuclear complexes that could cleave DNA, RNA or the model substrate ester effectively [17-23]. In our study, imidazolium ionic liquids containing dinuclear cyclen and their zinc (II) complexes were anticipated to protect DNA strands because of their unique molecular structure.

Herein, two imidazolium ionic liquids containing dinuclear cyclen moiety and their zinc (II) complexes were first synthesized and characterized. Their interaction with pUC19 plasmid DNA was studied. The results revealed that these complexes binding with DNA showed different characteristics from previous results in our group [21-23] due to the cation from imidazolium moiety.

\section{Results and Discussion}

\subsection{Preparation of dinuclear zinc (II) complexes}

The synthetic route of two zinc (II) complexes with imidazolium salt bridge was shown in Scheme 1. (Boc) $)_{2} \mathrm{O}$ could selectively protect cyclen to obtain tri-boc-protected cyclen. Compound 3 was obtained by the reaction between excessive p- or m-bis(bromomethyl) benzene and tri-bocprotected cyclen. Desired product $\mathbf{5}$ was obtained through two steps from imidazole and $\mathbf{3}$ by alkylation and formation of imidazolum cation. The Boc-protective groups were removed by adding dropwise the solution of trifluoroacetic acid (TFA) in dichloromethane. The target zinc (II) complexes with imidazolium salt groups were prepared from $\mathbf{6}$ with $\mathrm{Zn}\left(\mathrm{ClO}_{4}\right)_{2}$ in ethanol solution. 1a and $\mathbf{1 b}$ were characterized by elemental analysis.

\subsection{Interaction between ligands or their zinc (II) complexes and plasmid pUC19 DNA}

The interaction of macrocyclic polyamine metallic complexes with DNA was reported previously [21-23]. These complexes cleaved supercoiled plasmid DNA to produce open-circular form. Nevertheless the interaction of imidazolium ligands $\mathbf{6 a - b}$ and their zinc (II) complexes $\mathbf{1}$ with DNA was different from the reported models. The experimental results were shown in Figure 1-3.

Agarose gel electrophoresis demonstrated that ligands $\mathbf{6}$ and complexes $\mathbf{1}$ could bind with DNA. As shown in Figure 1, plasmid DNA control moved in the electric field (Lane 1), and DNA-1a complexes were retained around the sample well (Lanes 13 and 14). The reason why the DNA-1a complexes did not move toward the positive electrode lied in their charge and the large size [24]. On the other hand, lanes 15-18 showed that with the concentration of 1a decreased, plasmid DNA moved toward the 
positive electrode. The interaction of $\mathbf{1 b}$ with DNA showed similar phenomena as $\mathbf{1 a}$ due to their analogous molecule structure (Lanes 19-24).

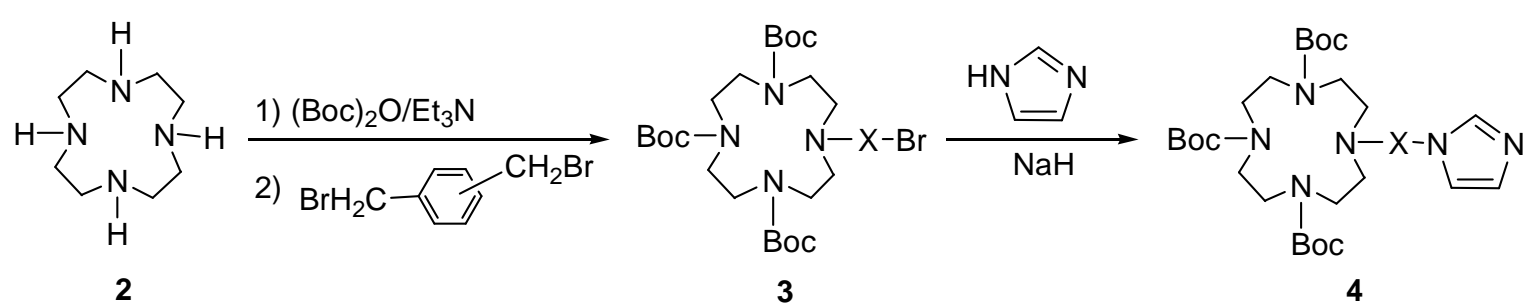

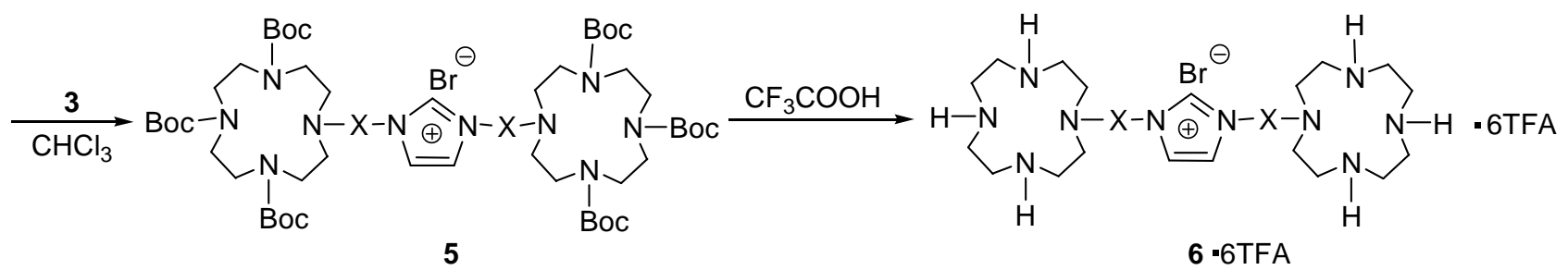

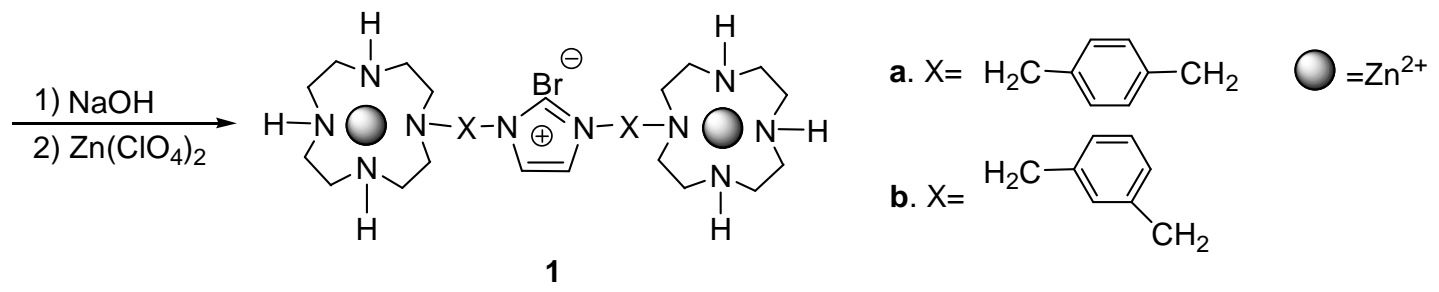

Scheme 1. Preparation of multinuclear Zinc (II) complexes.

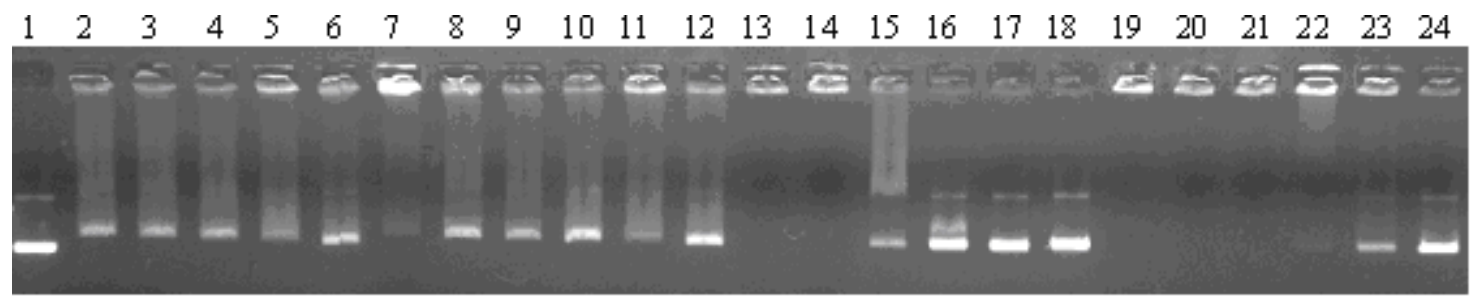

Figure 1. Effect of different ligands and complexes on the interaction with pUC19 DNA ( $7 \mu \mathrm{g} / \mathrm{ml})$ in a Tris- $\mathrm{HCl}$ buffer (100 mM, pH 7.4) at $37^{\circ} \mathrm{C}$ for $0.5 \mathrm{~h}$. Agarose gel electrophoresis diagram: lane 1, DNA control ; lanes 2-6, ligand: [6a] $=1.40,0.70,0.35,0.18,0.09 \mathrm{mM}$; lanes 7-12 ligand: $[\mathbf{6 b}]=1.40$, 0.70, 0.35, 0.18, 0.09, 0.05 mM; lanes 13-18 complex: [1a] = 0.144, 0.072, 0.036, 0.018, 0.009, $0.005 \mathrm{mM}$; lanes 19-24 complex: [1b] = 0.144, 0.072, 0.036, 0.018, 0.009, $0.005 \mathrm{mM}$.

Figure 1 also showed that DNA-6b complex could also be formed with high concentration of $\mathbf{6 b}$ (Lane 7). However, DNA-6a complex was not obvious enough as DNA-6b under same conditions (Lane 2). We therefore increased the concentration of $\mathbf{6 a}$ and the experiment results were shown in Figure 2. Ligand 6a could bind DNA to form DNA-6a complexes when the concentration of $6 \mathbf{a}$ was increased to $5.6 \mathrm{mM}$ (Figure 2, lane 2). 


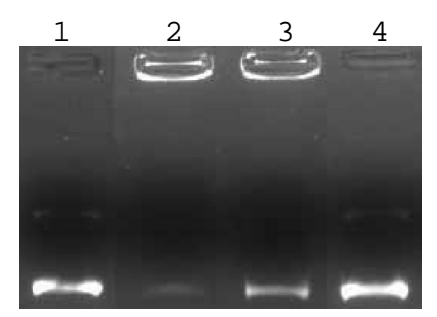

Figure 2. Effect of different concentration of ligands 6a on the interaction with pUC19 DNA ( $7 \mu \mathrm{g} / \mathrm{ml})$ in a Tris- $\mathrm{HCl}$ buffer $(100 \mathrm{mM}, \mathrm{pH} 7.4)$ at $37^{\circ} \mathrm{C}$ for $0.5 \mathrm{~h}$. Agarose gel electrophoresis diagram: lane 1,

DNA control ; lanes 2-4, ligand: [6a] = 5.6, 4.2, $2.8 \mathrm{mM}$.

Obviously zinc(II) complexes were more reactive than the free ligands. This might be due to that the cation density increased with the existence of zinc(II), it was more available for complexes to bind DNA with anion.

To investigate whether the macrocyclic polyamine imidazolium salt ligands and their zinc (II) complexes were efficient reagents in protecting DNA from being cleaved enzymatically, $0.1 \mathrm{U}$ of DNaseI was added respectively to the plasmid DNA and the DNA complexes containing $7 \mu \mathrm{g} / \mathrm{ml}$ of DNA. The results were shown in Figure 3. DNaseI could cleave DNA completely (Lane 2), which was used as control. It is obvious that both ligands 6 and complexes 1 could retard the cleavage of DNA efficiently (Lanes 3-6). It was illustrated that DNA could be protected by those compounds to avoid being cleaved. There might be a few possible reasons for the DNA protection based on imidazolium

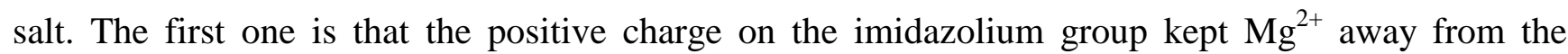
positively charged imidazolium salt. This would retard the enzymatic cleavage process, in which $\mathrm{Mg}^{2+}$ is needed. The second one is that DNA surface binding with imidazolium salt resulted in a variation of the DNA structure due to the size effect [4].

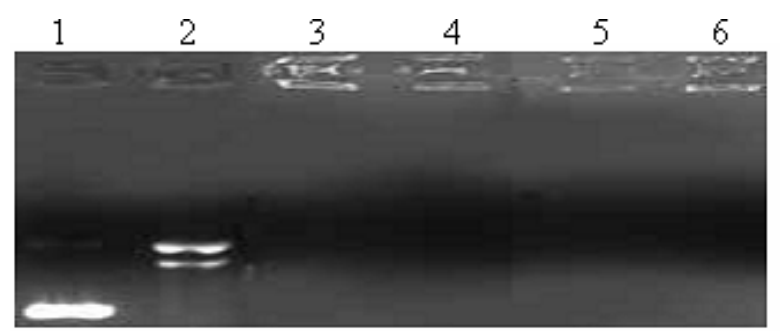

Figure 3. Effect of different ligands and complexes on the interaction with pUC19 DNA (7 $\mu \mathrm{g} / \mathrm{ml})$ with the existence of DNaseI in a Tris- $\mathrm{HCl}$ buffer $(100 \mathrm{mM}, \mathrm{pH} 7.4)$ at $37^{\circ} \mathrm{C}$ for $0.5 \mathrm{~h}$. Agarose gel electrophoresis diagram: lane 1, DNA control ; lane 2 DNA+ DNaseI; lane 3 DNA+ DNaseI + 6a; lane $4 \mathrm{DNA}+\mathrm{DNaseI}+\mathbf{6 b}$; lane $5 \mathrm{DNA}+\mathrm{DNaseI}+\mathbf{1 a}$; lane $6 \mathrm{DNA}+\mathrm{DNaseI}+\mathbf{1 b}$.

A typical imidazoluim 1-ethyl-3-methylimidazolium bromide (EMI) can not bind DNA, as shown in Figure 4. Clearly, macropolyamine moiety takes a significant role when ligands or complexes interact with DNA. Polyamine could be protonated then possesses more cation density to bind DNA with anion, maybe so ligands $\mathbf{6}$ and complexes $\mathbf{1}$ are more active than imidazolium without macropolyamine moiety. 


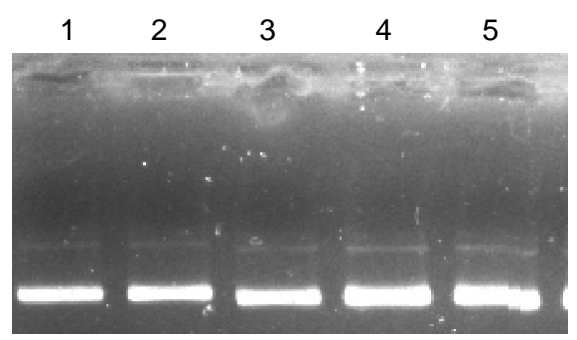

Figure 4. Effect of different concentration of 1-ethyl-3-methylimidazolium bromide (EMI) on the interaction with pUC19 DNA $(7 \mu \mathrm{g} / \mathrm{ml})$ in a Tris- $\mathrm{HCl}$ buffer $(100 \mathrm{mM}, \mathrm{pH} 7.4)$ at $37{ }^{\circ} \mathrm{C}$ for $0.5 \mathrm{~h}$. Agarose gel electrophoresis diagram: lane 1, DNA control ; lanes 2-5, ligand: $[\mathrm{EMI}]=$ 5.6, 11.2, 22.4, 44.8, $89.6 \mathrm{mM}$.

\subsection{Fluorescence quenching experiment}

Fluorescence quenching experiment was performed in Tris- $\mathrm{HCl} 100 \mathrm{mM}, \mathrm{pH} 7.4$ at room temperature to measure the binding affinities of compounds (6 and 1) with DNA. The extent of binding between the complexes and DNA could be determined by the fluorescence quenching of ethidium bromide intercalated to DNA.

According to the equation $r=1-\frac{F_{1}-F}{F_{1}-F_{0}} \times 100 \%$, in which $F_{0}$ is the initial fluorescence intensity of ethidium bromide; $F_{1}$ is the fluorescence intensity after ethidium bromide intercalating into the base pairs of dsDNA; and $F$ is fluorescence intensity in the presence of the ligands or complexes. The value of $r$ reflected the extent of the fluorescence quenched by the ligands or complexes (compared to $F_{1}-F_{0}$ ).

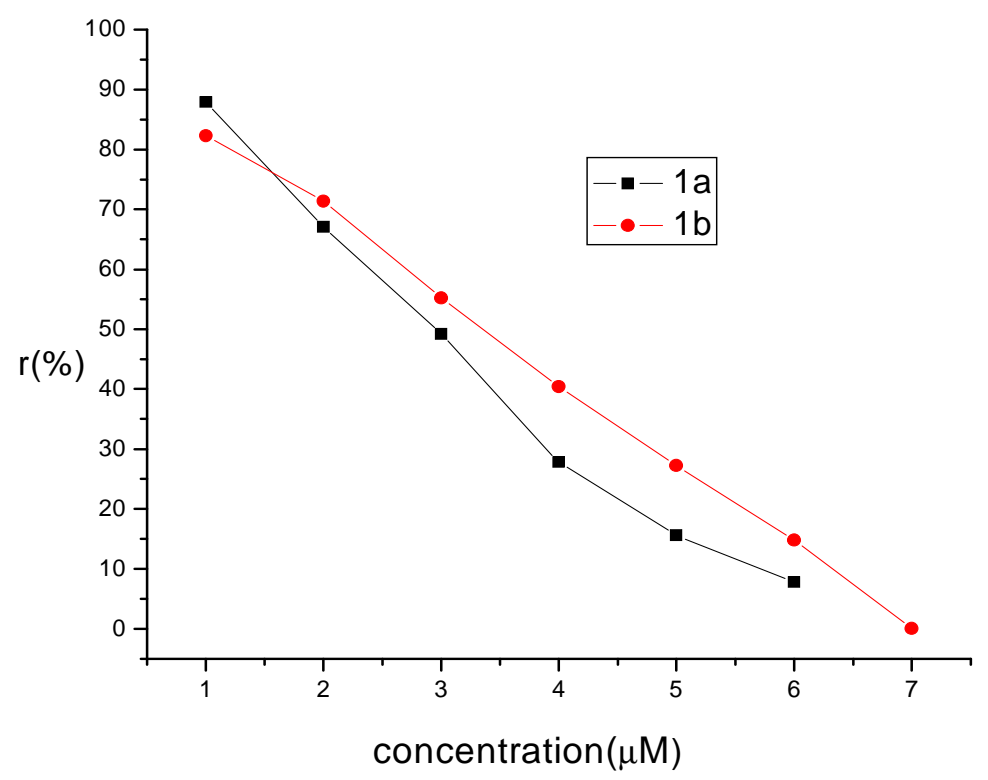

Figure 5. Fluorescence quenching curve of complexes at different concentration. 


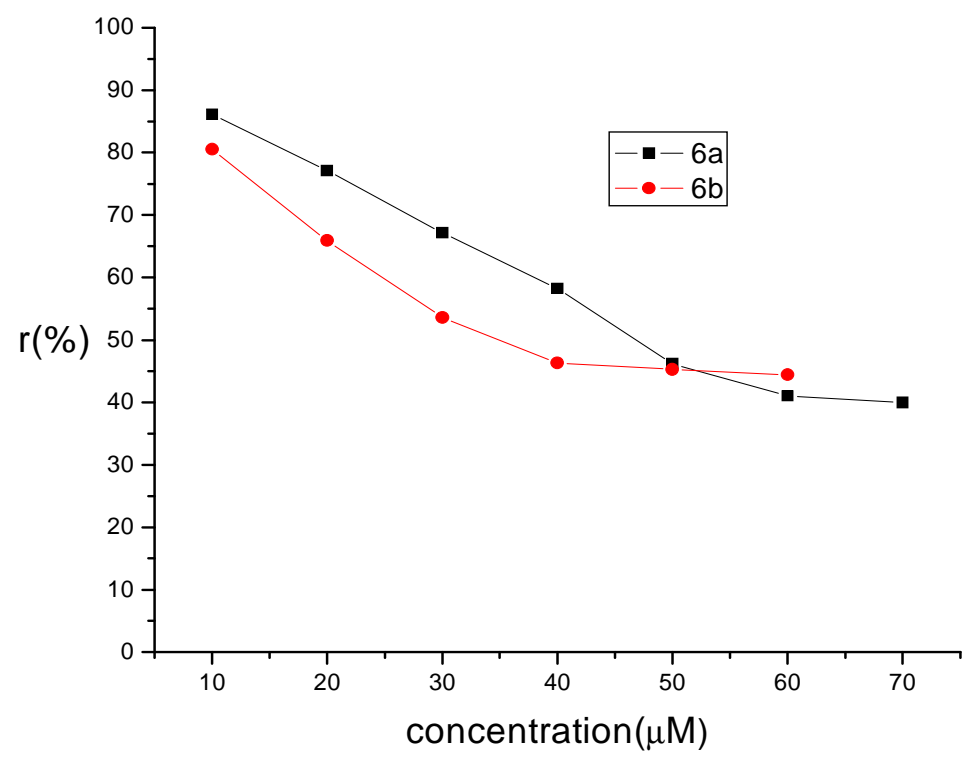

Figure 6. Fluorescence quenching curve of ligands at different concentration.

Figure 5 and Figure 6 showed that the fluorescence intensity decreased obviously associated with the increase of the concentration of complexes $\mathbf{1}$, which illustrated that complexes $\mathbf{1}$ could displace ethidium bromide effectively. Meanwhile, ligands $\mathbf{6}$ quenched the system fluorescence intensity with less efficiency comparing to $\mathbf{1}$, which showed that ethidium bromide is displaced partly by ligands $\mathbf{6}$. $\mathrm{C}_{50}$ value describes the concentration of certain compound when this compound could cause a $50 \%$ decrease (the value of $\mathrm{r}$ in Figure 5 and Figure 6 decrease to $50 \%$ ) in fluorescence intensity, and this value could show DNA-binding activity of certain compound. According to Figure 5 and Figure 6, the $\mathrm{C}_{50}$ values were the concentration $60,60,4,3 \mathrm{M}$ respectively. These results indicated that the free ligands were less active in the DNA-binding process than those of the metal complexes. The results were in accord with those of gel electrophoresis experiments.

\subsection{Conclusions}

In this paper, imidazolium ionic liquids containing dinuclear cyclen moiety and their zinc (II) complexes using an $m$ - or $p$-xylyl linkage were synthesized and characterized. Their interaction with DNA was detected by the method of agarose gel electrophoresis and fluorescence quenching. The results showed that DNA could be protected efficiently by the ligands and their zinc (II) complexes. Moreover, zinc (II) complexes were much more active than the free ligands. Imidazolium containing dinuclear cyclen moiety show much more interaction active with DNA than imidazolium without cyclen moiety. It will be useful in DNA separation, purification, and detection, and possibly in genetic engineering and gene therapy. Further studies are in progress. 


\section{Experimental}

\subsection{General information}

Compounds 1, 4- or 1, 3-bis(bromomethyl)benzene, cyclen, and 1, 4, 7- tris(tert-butyloxycarbonyl)1,4,7,10-tetraazacyclododecane(Boc 3 -cyclen), 1-bromomethyl-4(3)-(4',7',10'-tris-(tertbutyloxycarbonyl)-1',4',7',10'-tetraazacyclododecan-1-yl-methylene)benzene, 1-ethyl-3methylimidazolium bromide were prepared as described previously [25-28,12]. Electrophoresis grade agarose and plasmid DNA (pUC19) were purchased from Takara Biotechnology Company. All other reagents were used as received. Anhydrous acetonitrile $\left(\mathrm{CH}_{3} \mathrm{CN}\right)$, absolute chloroform $\left(\mathrm{CHCl}_{3}\right)$, dichloromethane $\left(\mathrm{CH}_{2} \mathrm{Cl}_{2}\right)$ were distilled from calcium hydride $\left(\mathrm{CaH}_{2}\right)$. All aqueous solutions were prepared from deionized or distilled water. IR spectra were recorded on a Shimadzu FTIR-4200 spectrometer as $\mathrm{KBr}$ pellets or thin films on $\mathrm{KBr}$ plates. The ${ }^{1} \mathrm{H}$ NMR and ${ }^{13} \mathrm{C}$ NMR spectra were measured on a Varian INOVA-400 spectrometer $(400 \mathrm{MHz})$ and the $\delta$ scale in parts per million was referenced to residual solvent peaks or internal tetramethylsilane (TMS). ESI mass spectra were performed on a Finnigan LCQDECA and high-resolution MS spectral data were recorded on a Bruker Daltonics Bio TOF. The fluorescence spectrum and intensity were measured with a F-4500 FL LS-50B spectrophotometer. Elemental analyses were performed using a Carlo-Elba 1106 elemental analytical instrument. Polarimetric measurement were taken on a Perkin-Elmer-341 automatic polarimeter. Electrophoresis apparatus was a biomeans stack II-electrophoresis system, PPSV-010. Bands were visualized by UV light and photographed using a gel documentation system by the estimation of the intensity of the DNA bands, recorded on an Olympus Grab-IT 2.0 annotating image computer system.

\subsection{General procedure for the synthesis of compounds $4 a-b$}

Imidazole $(0.2 \mathrm{mmol})$ and $\mathrm{NaH}(0.2 \mathrm{mmol})$ in $5 \mathrm{ml}$ of anhydrous acetonitrile was stirred at $0{ }^{\circ} \mathrm{C}$ for $1 \mathrm{~h}$. Then the solution of 1-bromomethyl-4 (3)-(4', 7', 10'-tris-(tert-butyloxycarbonyl)-1', 4', 7', 10'tetraazacyclododecan-1'-yl-methylene)benzene in $10 \mathrm{ml}$ of anhydrous acetonitrile was added dropwise in $1 \mathrm{~h}$. The mixture was kept stirring at room temperature for $3 \mathrm{~h}$. The reaction mixture was filtered to remove inorganic salt. After removing the solvent under reduced pressure, the mixture was purified by silica gel column chromatography (25:1 dichloromethane/ethanol) to yield the pure product as a white solid.

1-\{4'-[4",7",10"-tris(tert-butyloxycarbonyl)-1",4",7",10"-tetraazacyclododecan-1"-yl-methyl-

ene]benzyl \}imidazole (4a): Colorless amorphous solid. Yield: $81.4 \%$. IR ( $\left.\mathrm{KBr}, \mathrm{cm}^{-1}\right)$ : 3433, 2976, 1685, 1458, 1416, 1365, 1250, 1170, 1107, 980, 860, 772. ${ }^{1} \mathrm{H}$ NMR (400 MHz, $\mathrm{CDCl}_{3}, \mathrm{TMS}$ ): $\delta=1.36-1.41\left(\mathrm{~m}, 27 \mathrm{H}, \mathrm{C}\left(\mathrm{CH}_{3}\right)_{3}\right), 2.57\left(\mathrm{br}, 4 \mathrm{H}, \mathrm{NCH}_{2}\right), 3.19-3.51\left(\mathrm{~m}, 12 \mathrm{H}, \mathrm{NCH}_{2}\right), 3.66(\mathrm{~s}, 2 \mathrm{H}$, $\mathrm{NCH}_{2} \mathrm{Ar}$ ), 5.02 (s, $\left.2 \mathrm{H}, \mathrm{ArCH}{ }_{2} \mathrm{Ar}\right), 6.82(\mathrm{~s}, 1 \mathrm{H}$, imidazole-H), 7.01-7.03 (d, $3 \mathrm{H}$, imidazole-H, ArH), 7.16-7.18 (d, $2 \mathrm{H}, \mathrm{J}=8 \mathrm{~Hz}, \mathrm{ArH}), 7.49$ (s, $1 \mathrm{H}$, imidazole-H). ${ }^{13} \mathrm{C}$ NMR (100 MHz, $\mathrm{CDCl}_{3}$, TMS): 28.45, 28.69, 29.29, 47.93, 50.03, 50.49, 55.56, 56.67, 79.50, 119.23, 127.15, 129.78, 130.82, 135.10, 137.37, 155.85. ESI-MS: $\mathrm{m} / \mathrm{z}=643.6[\mathrm{M}+\mathrm{H}]^{+}$.

1-\{3'-[4",7",10"-tris(tert-butyloxycarbonyl)-1",4",7",10"-tetraazacyclododecan-1"-yl-methylene]benzyl \}imidazole (4b): Colorless amorphous solid. Yield: 84.1\%. IR (KBr, cm$\left.{ }^{-1}\right)$ : 3433, 2976, 1685, 1458, 1415, 1365, 1250, 1171, 1107, 980, 859, 772. ${ }^{1} \mathrm{H}$ NMR (400 $\mathrm{MHz}, \mathrm{CDCl}_{3}, \mathrm{TMS}$ ): 
$\delta=1.43-1.48\left(\mathrm{~m}, 27 \mathrm{H}, \mathrm{C}\left(\mathrm{CH}_{3}\right)_{3}\right), 2.62\left(\mathrm{~s}, 4 \mathrm{H}, \mathrm{NCH}_{2}\right), 3.24-3.57\left(\mathrm{~m}, 12 \mathrm{H}, \mathrm{NCH}_{2}\right), 3.72(\mathrm{~s}, 2 \mathrm{H}$, $\mathrm{NCH}_{2} \mathrm{Ar}$ ), 5.10 (s, $2 \mathrm{H}, \mathrm{ArCH}_{2} \mathrm{Ar}$ ), 6.89 (s, $1 \mathrm{H}$, imidazole-H), 7.00-7.29 (m, $5 \mathrm{H}$, imidazole-H, ArH), 7.54 (s, $1 \mathrm{H}$, imidazole-H). ${ }^{13} \mathrm{C}$ NMR (100 MHz, $\left.\mathrm{CDCl}_{3}, \mathrm{TMS}\right): 28.41,28.63,29.64,30.86,47.84$, 49.87, 50.64, 52.35, 54.48, 55.49, 56.77, 79.46, 119.20, 126.08, 128.85, 129.76, 136.16, 137.36, 155.82. ESI-MS: $\mathrm{m} / \mathrm{z}=643.4[\mathrm{M}+\mathrm{H}]^{+}$.

\subsection{General procedure for the synthesis of compounds $\mathbf{5} \boldsymbol{a}-\boldsymbol{b}$}

1-bromomethyl-4 (3)-(4', 7', 10'-tris-(tert-butyloxycarbonyl)-1',4',7',10'-tetraazacyclododecan-1'-ylmethylene)benzene $(0.60 \mathrm{mmol})$ was added to the solution of $4(0.55 \mathrm{mmol})$ in $15 \mathrm{ml}$ of $\mathrm{CHCl}_{3}$ and refluxed under $\mathrm{N}_{2}$ for 2 days. Then the reaction mixture was concentrated under reduced pressure. The remaining residue was purified by silica gel column chromatography ( $8: 1$ dichloromethane/ethanol) to yield the pure product as a white solid.

1,3-Bi $\left\{4^{\prime}-\left[4^{\prime \prime}, 7^{\prime \prime}, 10^{\prime \prime}\right.\right.$-tris(tert-butyloxycarbonyl)-1",4",7", 10"-tetraazacyclododecan-1"-ylmethylene]benzyl\}imidazolium bromide (5a): Colorless amorphous solid. Yield: $51.1 \%$. IR $\left(\mathrm{KBr}, \mathrm{cm}^{-1}\right): 3441,2975,1688,1560,1459,1416,1366,1250,1154,1103,1043,978,853,773 .{ }^{1} \mathrm{H}$ NMR (400 MHz, $\mathrm{CDCl}_{3}$, TMS): $\delta=1.42-1.47\left(\mathrm{~m}, 54 \mathrm{H}, \mathrm{C}\left(\mathrm{CH}_{3}\right)_{3}\right), 2.62\left(\mathrm{~s}, 8 \mathrm{H}, \mathrm{NCH}_{2}\right), 3.29-3.56$ (m, $24 \mathrm{H}, \mathrm{NCH}_{2}$ ), 3.74 (s, $4 \mathrm{H}, \mathrm{NCH}_{2} \mathrm{Ar}$ ), 5.52 (s, $4 \mathrm{H}, \mathrm{ArCH}_{2} \mathrm{Ar}$ ), 7.06 (s, $2 \mathrm{H}$, imidazole-H), 7.29-7.31 (d, $4 \mathrm{H}, J=8 \mathrm{~Hz}, \mathrm{ArH}), 7.38-7.39$ (br, $5 \mathrm{H}$, imidazole-H, ArH). ${ }^{13} \mathrm{C} \mathrm{NMR} \mathrm{(100} \mathrm{MHz}, \mathrm{CDCl}_{3}, \mathrm{TMS}$ ): 28.46, 28.66, 29.26, 29.68, 47.75, 50.00, 52.38, 53.37, 56.53, 79.46, 121.31, 123.27, 129.01, 131.20, 137.81, 155.78. HR-MS (ESI) Calcd for $\mathrm{C}_{65} \mathrm{H}_{105} \mathrm{~N}_{10} \mathrm{NaO}_{12}[\mathrm{M}-\mathrm{Br}+\mathrm{Na}]^{2+}: \mathrm{m} / \mathrm{z}=620.3963$. Found: 620.3932 .

1,3-Bi $\left\{3^{\prime}-\left[4^{\prime \prime}, 7^{\prime \prime}, 10^{\prime \prime}\right.\right.$-tris(tert-butyloxycarbonyl)-1",4",7",10"-tetraazacyclododecan-1"-ylmethylene]benzyl \}imidazolium bromide (5b): Colorless amorphous solid. Yield: $53.1 \%$. IR (KBr, $\left.\mathrm{cm}^{-1}\right): 3443,2976,1688,1560,1460,1416,1366,1250,1170,1097,1038,979,853,773 .{ }^{1} \mathrm{H}$ NMR (400 MHz, $\mathrm{CDCl}_{3}$, TMS): $\delta=1.41-1.48\left(\mathrm{~m}, 54 \mathrm{H}, \mathrm{C}\left(\mathrm{CH}_{3}\right)_{3}\right), 2.60\left(\mathrm{~s}, 8 \mathrm{H}, \mathrm{NCH}_{2}\right), 3.31-3.55(\mathrm{~m}, 24 \mathrm{H}$, $\mathrm{NCH}_{2}$ ), 3.74 (s, $\left.4 \mathrm{H}, \mathrm{NCH}_{2} \mathrm{Ar}\right), 5.52$ (s, $\left.4 \mathrm{H}, \mathrm{ArCH}_{2} \mathrm{Ar}\right), 7.17-7.18$ (m, $3 \mathrm{H}$, imidazole-H, ArH), 7.34(m, $8 \mathrm{H}$, imidazole-H, ArH). ${ }^{13} \mathrm{C} \mathrm{NMR}$ (100 MHz, $\left.\mathrm{CDCl}_{3}, \mathrm{TMS}\right): 28.44,28.63,29.66,47.78$, 49.96, 52.35, 52.39, 53.54, 54.81, 56.62, 79.53, 121.31, 127.91, 129.42, 132.50, 137.46, 138.57, 155.79. HR-MS (ESI) Calcd for $\mathrm{C}_{65} \mathrm{H}_{105} \mathrm{~N}_{10} \mathrm{O}_{12}[\mathrm{M}-\mathrm{Br}]^{+}: \mathrm{m} / \mathrm{z}=1217.7908$. Found: 1217.7893 .

\subsection{General procedure for the synthesis of TFA salts of compounds $\mathbf{6 a - b}$.}

Trifluoroacetic acid $(1.2 \mathrm{mmol})$ was added dropwise to a solution of $5(0.1 \mathrm{mmol})$ in $\mathrm{CH}_{2} \mathrm{Cl}_{2}(10$ $\mathrm{ml}$ ) at $0{ }^{\circ} \mathrm{C}$ under $\mathrm{N}_{2}$ atmosphere. The whole mixture was stirred for $4 \mathrm{~h}$. Then the reaction mixture was concentrated under reduced pressure. The remaining yellow oil liquid was washed three times with $\mathrm{CH}_{2} \mathrm{Cl}_{2}(5 \mathrm{ml})$ to obtain $6 \cdot \mathrm{TFA}$.

Trifluoroacetic acid salts of 1,3-bi[4'-(1",4",7",10"-tetraazacyclododecan-1"-ylmethylene)benzyl]imidazolium bromide (6a·6TFA): Yellow oil. Yield: $83.4 \%$. IR (KBr, $\left.\mathrm{cm}^{-1}\right): 3354$, 2924, 1683, 1559, 1457, 1348, 1258, 1120, 978, 823, 721. ${ }^{1} \mathrm{H}$ NMR (400 MHz, D $\left.\mathrm{D}_{2} \mathrm{O}\right): \delta=2.92-2.94$ (m, 8 H, NCH 2$), 3.05-3.26$ (m, 24 H, $\left.\mathrm{NCH}_{2}\right), 3.91$ (s, $\left.4 \mathrm{H}, \mathrm{ArNCH}_{2}\right), 5.42$ (s, $\left.4 \mathrm{H}, \mathrm{ArCH}_{2} \mathrm{Ar}\right), 7.44(\mathrm{~s}, 8$ $\mathrm{H}$, imidazole-H, ArH), 7.50 (s, $3 \mathrm{H}$, imidazole-H, ArH). ${ }^{13} \mathrm{C}$ NMR (100 MHz, $\left.\mathrm{D}_{2} \mathrm{O}\right): 41.90,42.08$, 43.57, 47.78, 52.63, 56.47, 111.65, 114.54, 117.43, 120.32, 122.32, 128.54, 129.89, 130.27, 130.82, 
133.98, 134.45, 135.45, 161.74, 162.10, 162.46, 162.82. HR-MS (ESI) Calcd for $\mathrm{C}_{35} \mathrm{H}_{57} \mathrm{~N}_{10}[\mathrm{M}-\mathrm{Br}]^{+}$: $\mathrm{m} / \mathrm{z}=617.4762$. Found: 617.4769 .

Trifluoroacetic acid salts of 1,3-bi[3'-(1",4",7",10"-tetraazacyclododecan-1"-ylmethylene)benzyl]imidazolium bromide (6b·6TFA). Yellow oil. Yield: $84.2 \%$. IR ( $\left.\mathrm{KBr}, \mathrm{cm}^{-1}\right): 3377$, 2962, 1685, 1457, 1353, 1260, 1162, 1037, 800, 733. ${ }^{1} \mathrm{H}$ NMR (400 MHz, DMSO, TMS): $\delta=2.91-2.94\left(\mathrm{~m}, 8 \mathrm{H}, \mathrm{NCH}_{2}\right), 3.05\left(\mathrm{~s}, 8 \mathrm{H}, \mathrm{NCH}_{2}\right), 3.20-3.27\left(\mathrm{~m}, 16 \mathrm{H}, \mathrm{NCH}_{2}\right), 3.92(\mathrm{~s}, 4 \mathrm{H}$, $\left.\mathrm{ArCH}_{2} \mathrm{~N}\right), 5.46\left(\mathrm{~s}, 4 \mathrm{H}, \mathrm{ArCH}_{2} \mathrm{Ar}\right), 7.38-7.43(\mathrm{~m}, 5 \mathrm{H}$, imidazole-H, ArH), 7.50-7.58 (m, $6 \mathrm{H}$, imidazole-H, ArH), ${ }^{13} \mathrm{C}$ NMR (100 MHz, $\left.\mathrm{D}_{2} \mathrm{O}\right): 41.82,42.00,43.88,47.69,52.48,56.21,111.81$, $114.70,117.60,120.49,122.71,128.90,130.85,133.56,135.08,135.45,135.57,162.37,162.72$, 163.08. HR-MS (ESI) Calcd for $\mathrm{C}_{35} \mathrm{H}_{57} \mathrm{~N}_{10}[\mathrm{M}-\mathrm{Br}]^{+}: \mathrm{m} / \mathrm{z}=617.4762$. Found: 617.4765 .

\subsection{General procedure for the synthesis of complexes $\mathbf{1} \boldsymbol{a}-\boldsymbol{b}$}

The trifluoroacetic acid salts of ligands $\mathbf{6 a - b}(0.1 \mathrm{mmol})$ were dissolved, respectively in the $5 \mathrm{ml}$ of ethanol and adjusted the aqueous solution to alkaline $(\mathrm{pH}>2)$ with $50 \%$ aqueous $\mathrm{NaOH}$. The solutions were extracted with $\mathrm{CH}_{2} \mathrm{Cl}_{2}(4 \times 15 \mathrm{ml})$. The combined organic layer was dried overnight by anhydrous $\mathrm{Na}_{2} \mathrm{SO}_{4}$ and the solutions were concentrated to obtain a white oils 6a-b. To the ethanol solutions $(5 \mathrm{ml})$ of $\mathbf{6 a - b}$, equimolar amount of salts $\mathrm{Zn}\left(\mathrm{ClO}_{4}\right)_{2}$ in $5 \mathrm{ml}$ of ethanol were added and the mixture were stirred at room temperature overnight. After filtration, the solids were washed with ethanol $(2 \times 5 \mathrm{ml})$, recrystallized from ethanol/ $\mathrm{H}_{2} \mathrm{O}(3: 1)$, and dried in vacuum to give pure zinc complexes.

1a: Yield: 44.2 \%. IR (KBr, cm $\left.{ }^{-1}\right): 3442,2924,1686,1635,1560,1457,1383,1108,847,787,626$. ${ }^{1} \mathrm{H}$ NMR (400 MHz, $\left.\mathrm{D}_{2} \mathrm{O}\right): \delta=2.81-2.83\left(\mathrm{~m}, 8 \mathrm{H}, \mathrm{NCH}_{2}\right), 3.01\left(\mathrm{~b}, 8 \mathrm{H}, \mathrm{NCH}_{2}\right), 3.08-3.11(\mathrm{~m}, 16 \mathrm{H}$, $\mathrm{ArNCH}_{2}$ ), 3.78 (s, $4 \mathrm{H}, \mathrm{ArCH}_{2} \mathrm{~N}$ ), 5.22 (s, $\left.4 \mathrm{H}, \mathrm{ArCH}_{2} \mathrm{Ar}\right), 7.16-7.33$ (m, $11 \mathrm{H}$, imidazole-H, ArH). Elemental analysis calcd for $\mathrm{C}_{35} \mathrm{H}_{57} \mathrm{Br}_{3} \mathrm{Cl}_{2} \mathrm{~N}_{10} \mathrm{O}_{8} \mathrm{Zn}_{2} \cdot \mathrm{HClO}_{4}$ : C, 32.64; H, 4.54; N, 10.88. Found C, 32.61; H, 4.42; N, 10.52 .

1b: Yield: $47.2 \%$. IR (KBr, $\left.\mathrm{cm}^{-1}\right): 3432,2922,1636,1559,1458,1400,1121,686,624 .{ }^{1} \mathrm{H}$ NMR (400 MHz, $\left.\mathrm{D}_{2} \mathrm{O}\right): \delta=2.81-2.84\left(\mathrm{~m}, 8 \mathrm{H}, \mathrm{NCH}_{2}\right), 2.97$ (b, $\left.8 \mathrm{H}, \mathrm{NCH}_{2}\right), 3.07-3.12\left(\mathrm{~m}, 16 \mathrm{H}, \mathrm{ArNCH}_{2}\right.$ ), 3.79 (s, $4 \mathrm{H}, \mathrm{ArCH}_{2} \mathrm{~N}$ ), 5.26 (s, $4 \mathrm{H}, \mathrm{ArCH}_{2} \mathrm{Ar}$ ), 7.26-7.34 (m, $11 \mathrm{H}$, imidazole-H, ArH). Elemental analysis calcd for $\mathrm{C}_{35} \mathrm{H}_{57} \mathrm{BrCl}_{4} \mathrm{~N}_{10} \mathrm{O}_{16} \mathrm{Zn}_{2}$ : C, 34.28; H, 4.68; N, 11.42. Found $\mathrm{C}, 34.29 ; \mathrm{H}, 4.76 ; \mathrm{N}$, 11.43 .

\subsection{Interaction between ligands or their zinc (II) complexes and plasmid pUC19 DNA}

Interaction between ligands or their zinc (II) complexes with plasmid pUC19 DNA was monitored by agarose gel electrophoresis. In a typical experiment, supercoiled pUC19 DNA (10 1, 0.025 g/l) in Tris-HCl (100 mM, pH 7.4) was treated with different concentration of ligands 6 or their zinc (II) complexes $\mathbf{1}$, followed by dilution with the Tris- $\mathrm{HCl}$ buffer to a total volume of $35 \mu$. The samples were then incubated at $37{ }^{\circ} \mathrm{C}$ for $1 \mathrm{~h}$, and loaded on a $1 \%$ agarose gel containing $1.0 \mathrm{~g} / \mathrm{ml}$ ethidium bromide. Electrophoresis was carried out at $40 \mathrm{~V}$ for $30 \mathrm{~min}$ in TAE buffer. Bands were visualized by UV light and photographed followed by the estimation of the intensity of the DNA bands using a Gel Documentation System. 


\subsection{Fluorescence quenching experiments}

All experiments were performed at room temperature in buffered aqueous solution (Tris- $\mathrm{HCl}$ $100 \mathrm{mM}, \mathrm{pH}$ 7.4). CT (calf thymus) DNA solution with optical density more than 1.8 at $260 \mathrm{~nm}$, the concentration is $1 \mathrm{~g} / \mathrm{ml} .10 \mu \mathrm{l}$ DNA solution and $80 \mu \mathrm{l}$ ethidium bromide with the concentration of $1 \mathrm{~g} / \mathrm{ml}$ was added, followed by different volume of $0.5 \mathrm{mM}$ complexes $(\mathbf{1 a}, \mathbf{1 b})$ or $5 \mathrm{mM}$ ligands $(\mathbf{6 a}$, 6b) solution, then buffer was added and adjusted the whole volume to $2.5 \mathrm{ml}$. After reacting for $0.5 \mathrm{~h}$, the fluorescence intensities were measured by fluorescence spectrophotometer.

\section{Acknowledgements}

This work was financially supported by the National Science Foundation of China (Nos. 20471038 and 20572075), Program for New Century Excellent Talents in University and Specialized Research Fund for the Doctoral Program of Higher Education.

\section{References}

1. Dong, S.M.; Fu, P.P.; Shirsat, R.N.; Hwang, H.M.; Leszczynski, J.;Yu, H.T. UVA light-induced DNA cleavage by isomeric methylbenz[a]anthracenes. Chem. Res. Toxicol. 2002, 15, 400-407.

2. Biggins, J.B.; Prudent, J.R.; Marshall, D.J.; Ruppen, M.; Thorson, J.S. A continuous assay for DNA cleavage: the application of "break lights" to enediynes, iron-dependent agents, and nucleases. Proc. Nalt. Acad. Sci. U.S.A. 2000, 97, 13537-13542.

3. Connelly, J.C.; De Leau, E.S.; Leach, D.R.F. DNA cleavage and degradation by the SbcCD protein complex from Escherichia coli. Nucleic. Acids. Res. 1999, 27, 1039-1046.

4. He, X.X.; Wang, K.; Tan, W.; Liu, B.; Lin, X.; He, C.; Li, D.; Huang, S.; Li, J. Bioconjugated nanoparticles for DNA protection from cleavage. J. Am. Chem. Soc. 2003, 125, 7168-7169.

5. Sohail, A.; Hayes, C.S.; Divvela, P.; Setlow, P. Bhagwat, A.S. Protection of DNA by $\approx / \beta$-type small, acid-soluble proteins from bacillus subtilis spores against cytosine deamination. Biochemistry 2002, 41, 11325-11330.

6. Gopal, V.; Prasad, T.K.; Rao N.M.; Takafuji, M.; Rahman, M.M.; Ihara, H. Synthesis and in vitro evaluation of glutamide-containing cationic lipids for gene delivery. Bioconjugate. Chem. 2006, 17, 1530-1536.

7. Su, M.; Cavallo, S.; Stefanini, S.; Chiancone, E.; Chasteen, N.D. The so-called listeria innocua ferritin is a Dps protein. iron incorporation, detoxification, and DNA protection properties. Biochemistry 2005, 44, 5572-5578.

8. Schwaiger, S.; Cervellati, R.; Seger, C.; Ellmerer, E.P.; About, N.; Renimel, I.; Godenir, C.; Andre, P.; Gafner, F.; Stuppner, H. Leontopodic acid - a novel highly substituted glucaric acid derivative from Edelweiss (Leontopodium alpinum Cass.) and its antioxidative and DNA protecting properties. Tetrahedron 2005, 61, 4621-4630.

9. Leone, A.M.; Weatherly, S.C.; Williams, M.E.; Thorp, H.H.; Murray, R.W. An ionic liquid form of DNA: redox-active molten salts of nucleic acids. J. Am. Chem. Soc. 2001, 123, 218-222. 
10. Wang, J.H.; Cheng, D.H.; Chen, X.W.; Du, Z.; Fang, Z.L. Direct extraction of double-stranded DNA into ionic liquid 1-butyl-3-methylimidazolium hexafluorophosphate and its quantification. Anal. Chem. 2007, 79, 620-625.

11. Ohno, H; Nakamura, N. Ion conductive characteristics of DNA film containing ionic liquids. $J$. Electrochem. Soc. 2001, 148, E168-170.

12. Nishimura, N; Normura, Y; Nakamura, N; Ohno, H. DNA strands robed with ionic liquid moiety. Biomaterials 2005, 26, 5558-5563.

13. Jacobsen, F.E.; Lewis, J.A.; Cohen, S.M.A new role for old ligands: discerning chelators for zinc metalloproteinases. J. Am. Chem. Soc. 2006, 128, 3156-3157.

14. Lukes, I.; Kotek, J.; Vojtisek, P.; Hermann, P. Complexes of tetraazacycles bearing methylphosphinic/phosphonic acid pendant arms with copper(II), zinc(II) and lanthanides(III). A comparison with their acetic acid analogues. Coord. Chem. Rev. 2001, 216, 287-312.

15. Bencini, A.; Berni, E.; Bianchi, A.; Giorgi, C.; Valtancoli, B.; Chand, D.K.; Schneider, H. Proton and $\mathrm{Cu}$ (II) binding to tren-based tris-macrocycles. Affinity towards nucleic acids and nuclease activity. Dalton.Trans. 2003, 5, 793-800.

16. Benniston, A.C.; Gunning, P.; Peacock, R.D. Synthesis and binding properties of hybrid cyclophane-azamacrocyclic receptors. J. Org. Chem. 2005, 70, 115-123.

17. Mancin, F.; Scrimin, P.; Tecilla, P.; Tonellato, U. Artificial metallonucleases. Chem. Commun. 2005, 20, 2540-2548.

18. Liu, C.L.; Yu, S.W.; Li, D.F.; Liao, Z.R.; Sun, X.H.; Xu, H.B. DNA hydrolytic cleavage by the diiron(III) complex $\mathrm{Fe}_{2}(\mathrm{DTPB})(\boldsymbol{\mu}-\mathrm{O})(\boldsymbol{\mu}-\mathrm{Ac}) \mathrm{Cl}\left(\mathrm{BF}_{4}\right)_{2}$ : comparison with other binuclear transition metal complexes. Inorg. Chem. 2002, 41, 913-922.

19. Deck, K.M.; Tseng, T.A.; Burstyn, J.N. Triisopropyltriazacyclononane copper(II): an efficient phosphodiester hydrolysis catalyst and DNA cleavage agent. Inorg. Chem. 2002, 41, 669-677.

20. Ren, R.; Yang, P.; Zheng, W.J.; Hua, Z.C.A simple copper(II)-L-histidine system for efficient hydrolytic cleavage of DNA. Inorg Chem. 2000, 39, 5454-5463.

21. Xiang, Q.X.; Zhang, J.; Liu, P.Y.; Xia, C.Q.; Zhou, Z.Y.; Xie, R.G.; Yu, X.Q. Dinuclear macrocyclic polyamine zinc(II) complexes: Syntheses, characterization and their interaction with plasmid DNA. J. Inorg. Biochem. 2005, 99, 1661-1669.

22. (a). Xia, C.Q.; Jiang, L.; Zhang, J.; Chen, S.Y.; Lin, H.H.; Tan, X.Y.; Yue, Y.; Yu, X.Q. The conjugates of uracil-cyclen $\mathrm{Zn}$ (II) complexes: Synthesis, characterization, and their interaction with plasmid DNA. Bioorg. Med. Chem. 2006, 14, 5756-5764; (b). Li, Q.L.; Huang, J.; Wang, Q.; Jiang, N.; Xia, C.Q.; Lin, H.H.; Wu, J.; Yu, X.Q. Monometallic complexes of 1,4,7,10tetraazacyclododecane containing an imidazolium side: Synthesis, characterization, and their interaction with plasmid DNA. Bioorg. Med. Chem. 2006, 14, 4151-4157; (c). Wang, X.Y.; Zhang, J.; Li, K.; Jiang, N.; Chen, S.Y.; Lin, H.H.; Huang, Y.; Ma, L.J.; Yu, X.Q. Synthesis and DNA cleavage activities of mononuclear macrocyclic polyamine zinc(II), copper(II), cobalt(II) complexes which are linked with uracil. Bioorg. Med. Chem. 2006, 14, 6745-6751; (d). Fang,Y.G.; Zhang, J.; Chen, S.Y.; Jiang, N.; Lin, H.H.; Zhang, Y.; Yu, X.Q. Chiral multinuclear macrocyclic polyamine complexes: Synthesis, characterization and their interaction with plasmid DNA. Bioorg. Med. Chem. 2007, 15, 696-701; (e). Chen, S.Y.; Huang, Y.; Zhang. G.L.; Cheng, H.; Xia, 
C.Q.; Ma, L.J.; Yu, H.; Yu, X.Q. Synthesis of a cyclen-functionalized $\alpha$-amino acid and its incorporation into peptide sequence. Synthesis 2005, 6, 888-892.

23. Peng, W.; Liu, P.Y.; Jiang, N.; Lin, H.H.; Zhang, G.L.; Liu, Y.; Yu, X.Q. Dinuclear macrocyclic polyamine zinc(II) complexes linked with flexible spacers: Synthesis, characterization, and DNA cleavage. Bioorg. Chem. 2005, 33, 374-385.

24. Kostiainen, M.A.; Hardy, J.G.; Smith, D.K. High-affinity multivalent DNA binding by using lowmolecular-weight dendrons. Angew. Chem. Int. Ed. 2005, 44, 2556-2559.

25. Wenner, W. Bis(bromomethyl) compounds. J. Org. Chem. 1952, 17, 523-528.

26. Athey P.S.; Kiefer G.E. A new facile synthesis of 1,4,7,10-tetraazacyclododecane: cyclen. J. Org. Chem. 2002, 67, 4081-4085.

27. Brandes, S.; Gros, C.; Denat, F.; Pullumbi, P.; Guilard, R. New facile and convenient synthesis of bispolyazamacrocycles using Boc protection. Determination of geometric parameters of dinuclear copper(II) complexes using ESR spectroscopy and molecular mechanics calculations. Bull. Soc. Chim. Fr. 1996, 133, 65-73.

28. Kimura, E.; Kikuchi, M.; Kitamura, H.; Koike, T. Selective and efficient recognition of thymidylylthymidine (TpT) by bis(ZnII-cyclen) and thymidylylthymidylyl-thymidine (TpTpT) by tris(ZnII-cyclen) at neutral pH in aqueous solution. Chem. Eur. J. 1999, 11, 3113-3123.

(C) 2007 by MDPI (http://www.mdpi.org). Reproduction is permitted for noncommercial purposes. 